\title{
PENERAPAN MODEL CREATIVE PROBLEM SOLVING BERBASIS EKSPERIMEN UNTUK MENINGKATKAN KEMAMPUAN KONITIF DAN KOMUNIKASI ILMIAH DALAM PEMBELAJARAN FISIKA
}

\author{
Siti Nurlina Ripani ${ }^{1 *}$ Nana $^{2}$ \\ ${ }^{1}$ Mahasiswa Program Studi Pendidikan Fisika Universitas Siliwangi \\ ${ }^{2}$ Dosen Program Studi Pendidikan Fisika Universitas Siliwangi \\ *email korespondensi: sitiripani7@gmail.com
}

\begin{abstract}
ABSTRAK: Tujuan penulisan ini untuk mendeskripsikan penerapan model Creative Problem Solving (CPS) berbasis eksperimen untuk meningkatkan kemampuan kognitif dan komunikasi ilmiah dalam pembelajaran Fisika. Penulisan ini dilatarbelakangi oleh siswa yang harus memiliki berbagai kompetensi beberapa diantaranya yaitu kemampuan kognitif dan komunikasi sehingga diperlukan pembelajaran yang mampu meningkatkan pemahaman materi pembelajaran dan komunikatif yang melibatkan siswa dalam proses pembelajaran. Untuk itu model pembelajaran yang dipilih untuk memecahkan permasalahan tersebut dengan model Creative Problem Solving berbasis eksperimen. Metode yang digunakan dalam penulisan ini adalah dengan studi kepustakaan dengan mengkaji beberapa literatur untuk dianalisis dan dibuat kesimpulan. Hasil penulisan menunjukan bahwa penerapan model Creative Problem Solving berbasis eksperimen untuk meningkatkan kemampuan komunikasi ilmiah. Model creative problem solving diterapkan dengan beberapa langkah antara lain; siswa melakukan klarifikasi berbagai masalah untuk dipecahkan, setelah masalah dipilih untuk kemudian siswa melakukan eksperimen, selanjutnya melakukan proses evaluasi dan seleksi untuk menemukan solusidari masalah yang ditemukan, setelah itusiswa melakukan implementasi kepada kelompok lain secara langsung. Pembelajaran Creative Problem Solving berbasis eksperimen dapat mengaktifkan partiipasi siswa di kelas.

Kata Kunci : Creative Problem Solving, Eksperimen, Kemampuan Komunikasi Ilmiah, Kemampuan Kognitif
\end{abstract}

\section{PENDAHULUAN}

Pembelajaran fisika diharapkan dapat menumbuhkan kemampuan berpikir, bekerja dan bersikap ilmiah, serta berkomunikasi. Sumber daya manusia pada paradigm pendidikan nasional abad 21 harus memiliki beberapa kompetensi, yaitu: (1) kemampuan berpikir kritis dan pemecahan masalah, (2) kemampuan berkomunikasi dan kerjasama, (3) kemampuan mencipta dan memperbaharui, (4) literasi teknologi informasi dan komunikasi, (5) kemampuan belajar kontekstual, dan (6) kemampuan informasi dan literasi media (Oktaviani, 2015:27). 
Dengan tuntutan-tuntutan tersebut maka diperlukan suatu model pembelajaran yang tepat sehingga mampu merealisasikan beberapa tuntutannya. Menurut Yu Je Lee (dalam Nana, 2018:191) Secara garis besar model juga harus fleksibel karena didasarkan pada situasi dan kondisi di sekolah dengan tujuan untuk merangsang daya kreatif siswa.

Model pembelajaran yang digunakan jangan hanya model pembelajaran tradisional yang akan membuat siswa tidak paham dengan materi pembelajaran fisika, sesuai dengan yang dinyatakan oleh Silalahi (dalam Nana, 2019:1) bahwa $60 \%$ dari siswa berpendapat bahwa fisika adalah pelajaran yang sulit dipahami dan kurang menarik dipelajari. Hal ini dikarenaakn model pembelajaran yang sangat sering digunakan adalah model pembelajaran tradisional yakni ceramah, jarang sekali menggunakan model yang bervariasi. Menurut Druxes (dalam Nana, 2019:1) hal ini menyebabkan isi masa pelajaran Fisika dianggap sebagai bahan hafalan, sehingga siswa tidak memahami konsep yang sebenarnya.

Salah satu model yang mampu menjadi solusi yaitu Creative Problem Solving (CPS). Hikmah (dalam Oktaviani, 2015:27) menyatakaan bahwa penerapan pembelajaran Creative Problem Solving (CPS) dapat meningkatkan hasil belajar fisika dan aktivitas belajar siswa. Membiasakan siswa dalam mencari sendiri jawaban dari permasalahan yang dimunculkan dapat meningkatkan pemahaman konsep dan keterampilan komunikasi siswa dalam pembelajaran fisika.

Menurut Rahmawati (2014: 41) dengan mendesain pembelajaran, salah satunya dengan membuat siswa belajar secara berkelompok dan melakukan suatu percobaan atau eksperimen dapat membuat siswa lebih aktif dalam kegiatan pembelajaran. Selain membuat siswa menjadi lebih aktif, siswa dapat menggunakan keterampilan yang dimilikinya dari pembelajaran yang dilakukan. Maka dalam hal ini, perlunya membahas bagaimana cara menerapkan model Creatve Problem Solving berbasis eksperimen untuk meningkatkan kemampun kognitifdan komunikasi ilmiah dalam pembelajaran Fisika.

\section{METODE PENELITIAN}

Metode yang digunakan dalam penulisan ini berupa studi kepustakaan. Data dikumpulkan untuk dianalisis kemudian disajikan dalam hasil dan pembahasan agar dapat dibuat kesimpulan.

\section{HASIL DAN PEMBAHASAN}

\subsection{Creative Poblem Solving}

Pada model Creative Problem Solving (CPS) digunakan pemusatan pada pengajaran dan keterampilan pemecahan masalah, yang diikuti dengan penguatan keterampilan. Ketikasiswa dihadapkan pada suatu permasalahan maka siswa dapat melakukan keterampilan memecahkan masalah untuk memilih dan mengembangkan ide serta pemikirannya. Siswa tidak hanya menggunakan cara menghafal tanpa proses berpikir, tetapi menggunakan keterampilan memecahan 
masalah yang mengembangkan proses berpikir (Pepkin, dalam Oktaviani, 2015: 27)

Menurut Puccio (dalam Oktaviani, 2015: 27) Creative Problem Solving (CPS) sebagai model keterampilan berpikir yang salah satu fungsinya adalah untuk meningkatkan proses berpikir sehingga lebih mampu dalam mengatasi kesulitan-kesulitan.

Langkah-langkah dalam model Creative Problem Solving antara lain sebagai berikut, proses pemecahan masalah dengan kreatif dengn menyeleksi informasi baru, masalah yang telah diidentifikasi kemudian dikonsep secara komprehensif, proses malah yangtelah dikonsep untuk menemukan solusi dari masalah yang nyata (Basadur et al, dalam Nana, 2018:192).

\subsection{Eksperimen}

Menurut Sagala eksperimen adalah percobaan untuk mengamati suatu objek, menganalisis data, membuktikan dan menarik kesimpulan sendiri tentang suatu objek dan membuktikan suatu pertanyaan atau hipertesis tertentu. Sedangkan metode eksperimen dalam pembelajaran adalah cara penyajian bahan pelajaran yang memungkinkan siswa melakukan percobaan untuk membuktikan sendiri suatu pertanyaan atau hipotesis yang dipelajari (dalam Astutik, 2012:148).

Dalam proses pembelajaran dengan metode eksperimen siswa diberi kesempatan untuk mengalami sendiri atau mengikuti proses, mengamati suatu objek, menganalisis data, membuktikan dan mennarik kesimpulan sendiri tentang suatu proses, keadaan atau proses tertentu. Peranan guru dalam metode eksperimen adalah memberi bimbingan agar eksperimen itu dilakukan dengan teliti sehingga tidak terjadi kekeliruan atau kesalahan (Astutik, 2012: 148).

\subsection{Kemampuan Kognitif}

Menurut Yuliani (dalam Jawati, 2013: 253) kemampuan kognitif adalah suatu proses berfikir untuk menghubungkan, menilai dan mempertimbangkan suatu kejadian atau peristiwa.

Sedangkan menunrut Anderson \& Krathwohl (dalam Siswanto dkk, 2014:106) kemampuan kognitif merupaakan kegiatan mental dari tahap dasar ke tahap yang lebih tinggi yang dilakukan oleh seseorang dalam berpikir yang meliputi aspek mengingat $\left(\mathrm{C}_{1}\right)$, memahami $\left(\mathrm{C}_{2}\right)$, mengaplikasikan $\left(\mathrm{C}_{3}\right)$, menganalisis $\left(\mathrm{C}_{4}\right)$, mengevaluasi $\left(\mathrm{C}_{5}\right)$, dan mencipta $\left(\mathrm{C}_{6}\right)$.

\subsection{Kemampuan Komunikasi}

Komunikasi adalah transmisi informasi, baik bersifat verbal maupun non verbal. Berbagai perspektif definisi proses komunikasi iniah yang akan mengantarkan pada pendekatan komunikasi ilmiah yang lebih banyak terjadi dalam dimensi riset, inquiry, dan invensi dari para ilmuan (researcher) (Motley dalam Nana, 2019:3).

Sedangkan menurut Dicky (dalam Nana, 2019:3) komunikasi adalah suatu proses penyampaian pesan (ide, gagasan) dari satu pihak kepada pihak lain agarterjadi saling mempengaruhi diantara keduanya. Pada umumnya, komunikasi 
dilakukan dengan menggunakan kata-kata (lisan) yang dapat dimengerti oleh kedua belah pihak. Apabila tidak ada bahasa verbal yang dapat dimengerti oleh kedunya, komunikasi masih dapat dilakukan dengan menggunakan gerak-gerik badan, menunjukan sikap tertentu, misalya tersenyum, menggelengkan kepala, mengangkat bahu, cara seperti ini disebut komunikasi dengan bahasa nonverbal atau bahasa isyarat.

Proses komunikasi ilmiah dapat mempelajari berbagai bidang ilmu (fisika, biologi, sosial, psikologi, humaniora, teknologi) memanfaatkn dan menyebarkan informasi melalui saluran formal dan informal. Kajian komunikasi ilmiah mencakup perkembanganilmu pengetahuan, hubunganantara peneliti dalam berbagai disiplin ilmu, pemanfaatan dan mebutuhan informasi dari kelompok pemustaka, serta metode komunikasi baik foral maupun informal. Dengan demikian komunikasi ilmiah adalah komunnikasiyang umumnya berkaitan dengan kegiatan-kegiatan penelitian atau penyelidikan, khususnya di lingkungan akademik. Pada pembelajaran sekolah menengahdapat diwujudkan dengan adanya percobaan, penyelesaian sebuah masalah, pembuatan karya ilmiah dan lain sebagainya (Lougee dalam Nana, 2019: 3)

Komunikasi ilmiah menuntut kemampuan berbahasa degan jelas. Hal ini berarti kata-katayang digunakan harus diungkapkan secara eksplisit untuk mencegah ksalahpahaman makna. Oleh karena itulah dalam komunikasi ilmiah sering ditemukan definisi dari kata-kata yang dipergunakan. Hal ini dilakukn agar komunikasi tidakmemberi arti atau definisi yang berbeda dari makna yang dimaksudkan komunikator. Jika hal tersebut terjadi, maka akan mengasilkan proses berpikir yang berbeda pula (Nana, 2019:3)

\subsection{Penerapan Model Creative Problem Solving Berbasis Eksperimen Untuk Meningkatkan Kemampuan Kognitif dan Kemampuan Komunikasi Ilmiah}

Model Creative Problem Solving digunakan pemusatan pada pengajaran dan keterampilan pemecahan masalah, yang diikuti dengan penguatan keterampilan. Ketika siswa dihadapkan pada suatu permasalahan maka siswa dapat melakukan keterampilan memecahkan masalah untuk memilih dan mengembangkan idesertapemikirannya, tidak hanya menggunakancara menghafal tanpa proses berpikir. Melalui pembelajaran Creative Problem Solvig, siswa mengkonstruksi makna atau pengertian berdasarkan pngetahuan awal yang dimiliki, mengintegrasikan pengetahuan yang baru kedalam skema yang telah ada dalam pemikiran siswa sendiri (Pepkin dalam Oktaviani, 2015:28).

Hikmah \& Natsir (dalam Oktaviani, 2015: 28) menyatakan bahwa penerapan pembelajaran berbasis masalah dengn tipe CPS dapat meningkatkan ketuntasan belajar siswa. Pembelajaran model CPS dapat meningkatkan kemampuan pemecahan masalah dan aktivitas belajar siswa (Mahardika dalam Oktaviani, 2015:28-29). 
Dengan hal tersebut, maka model pembelajaran Creative Problem Solving mampu meningkatkan kemampuan kognitif karena membuat siswa berpikir kreatif dan mandiri dan mampu meningkatkan pemahaman konsep, sesuaidengan yang dinyatakan oleh Semiawan (dalam Oktaviani, 2015:29) bahwa pembelajaran melalui pendekata pemecahan maalah merupakan pembelajaran kognitif induktif yang membuat siswa berpikir kreatif dan mandiri serta dapat meningkatkan pemahaman konsep.

Model pembelajaran CPS memberikan kesempatan seluas-luasnya kepada siswa untuk mengemukakan gagasan kreatifnya untuk menyelesaikan suatu permasalahan (Hikmah dalam Oktaviani, 2015: 29). Menurut Siregar (dalam Oktaviani: 2015:29) penerapan model pembelajaran CPS dapat mengingkatkan aktivitas siswa. Lo (dalam Oktaviani, 2015:29) juga menyatakan bahwa terdapat peningkatan komuikasi lisan pada siswa yang mengikuti pembelajaran dengan metode diskusi.

Berdasarkan hasil penelitian yang dilakukan oleh Oktaviani (2015: 29) bahwa keterampilan komunikasi dengan pemahaman konsep menunukkan adanya korelasi positif bahwa peningkatan pemahaman konsep siswa mempengaruhi keterampilan komunikasi siswa.

\section{PENUTUP}

Dari berbagai pembahasan yang telah dijabarkan dapat ditarik kesimpulan dan dimaknai bahwa model pembelajaran creative problem solving berbasis eksperimen mampu meningkatkan kemampuan kognitif dan komunikasi siswa karena dengan model pembelajaran tersebut menuntut siswa untuk menyelesaikan permasalahannya secara mandiri yang mempu meningkatkan pemahaman siswa atau kemampuan kognitif serta metode diskusi untuk meningkatkan kemampuan komunikasi.

\section{UCAPAN TERIMA KASIH}

Terima kasih kepada semua pihak yang telah membantu demi kesempurnaan artikel ini menjadi lebih baik terutama kepada Bapak Dr. Nana, M.Pd. selaku dosen pengampu Fisika Sekolah II atas bimbingannya.

\section{DAFTAR PUSTAKA}

Astutik, Sri. (2012). Meningkaatkan Hasil Belajar Siswa Dengan Model Siklus Belajar (Learning Cycle 5E) Berbasis Eksperimen Pada Pembelajaran Sains Di SDN Patrang 1 Jember. Jurnal Ilmu Pendidikan Sekolah Dasar 1(2), 143-153 [Online]. Tersedia: http://pgsd.fkkip.unej.ac.id/wpcontent/uploads/sites/5/2015/05/Jurnal-JIPSD-Vol-1-2-2012.1.pdf\#page=16 [9 Februari 2020]

Busyairi, Ahmad \& Sinaga, P. (2015). Strategi Pembelajaran Creative Problem Solving (CPS) Bersasis Eksperimen Untuk Meningkatkan Kemampuan Kognitif dan Keterampilan Berpikir Kreatif. Jurnal Pengajaran MIPA, 20(2), 133-143 [Online].

Tersedia: 
http://journal.fpmipa.upi.edu/index.php/jpmipa/article/view/576 [8 Februari 2020]

Jawati, Romaikis. (2013). Peningkatan Kemampuan Kognitif Anak Melalui Permainan Ludo Di PAUD Habibul Ummi II. Spektrum PLS 1(1), 250-263 [Online].

Tersedia:

http://ejournal.unp.ac.id/index.php/pnfi/article/view/1537 [9 Februari 2020]

Nana, \& Pramono, H. (2019). Upaya Peningkatan Kemampuan Kognitif dan Komunikasi Ilmiah Siswa Kelas X MIA 1 SMA Negeri1 Ciamis Menggunakan Model Pembelajaran Inquiry. Difraction 1(1), 1-10[Online]. Tersedia: http://jurnal.unsil.ac.id/index.php/Diffraction/article/view/812 [8 Februari 2020]

Nana. (2018). Penerapan Model Creative Problem Solving Berbasis Blog Sebagai Inovasi Pembelajaran Di Sekolahh Menengah Atas Dalam Pembelajaran Fisika. Seminar Nasional Fisika dan Aplikasinya 190-195 [Online]. Tersedia: https://jurnal.uns.ac.id/prosidingsnfa/article/view/28544 [8 Februari 2020]

Oktaviani, A.N. \& Nugroho, S.E. (2015). Penerapan Model Creative Problem Solving Pada Pembelajaran Kalor Untuk Meningkatkan Pemahaman Konsep dan Keterampilan Komunikasi. Unnes Physics Education Journal 4(1) 26-31 [Online]. Tersedia: https://journal.unnes.ac.id/sju/index.php/upej [8 Februari 2020]

Rahmawati, D, Nugroho, S.E., Putra, N.M.D. (2014). Penerapan Model Pembelajaran Kooperatif Tipe Numbered Head Together Berbasis Eksperimen Untuk Meningkatkan Keterampilan Proses Sains Siswa SMP. Unnes Physics Education Journal 3(1), 40-45 [Online]. Tersedia: http://journal.unnes.ac.id/sju/index.php/upej [8 Februari 2020]

Siswanto, Kaniawati, I. \& Suhandi A. (2014). Penerapan Model Pembelajaran Pembangkit Argumen Menggunakan Metode Saintifik Untuk Meningkatkan Kemampuan Kognitif dan Keterampilan Berargumentasi Siswa. Jurnal Pendidikan Fisika Indonesia 10 (2), 104-116 [Online]. Tersedia: http://journal.unnes.ac.id/nju/indeks.php/jpfi [9 Februari 2020] 